\title{
Retinal Ganglion Cell
}

National Cancer Institute

\section{Source}

National Cancer Institute. Retinal Ganglion Cell. NCI Thesaurus. Code C12642.

An output neuron in the retina that receives visual signals from photoreceptors via interneurons, and transmits the information to the thalamus, hypothalamus, and superior colliculus of the brain through the optic nerve. 